\title{
Fishing mortality versus natural predation on diurnally migrating sandeels Ammodytes marinus
}

\author{
Georg H. Engelhard*, Jeroen van der Kooij, Ewen D. Bell, John K. Pinnegar, \\ Julia L. Blanchard, Steven Mackinson, David A. Righton
}

Centre for Environment, Fisheries and Aquaculture Science, Pakefield Road, Lowestoft NR33 0HT, UK

\begin{abstract}
Do large-scale industrial fisheries for sandeels impact 'human consumption' fishes by depriving them of food? In the North Sea, most sandeel fishing takes place on the Dogger Bank during spring. Here, we studied sandeel-fishery and sandeel-predatory fish interactions in 2 sampling grids, focussing on (1) how localised sandeels are distributed during the day (when feeding pelagically) and at night (when buried in the seabed); (2) how precisely the fishery can target localised sandeel concentrations; and (3) how tightly day/night sandeel distributions are linked to the local abundance of predatory fishes and their sandeel consumption. Sandeel abundance differed widely between both grids. Within each grid, marked day/night differences in distributions indicated extensive diurnal migrations, with centres of gravity of day and night distributions up to $15 \mathrm{~km}$ apart. Fishing effort was tightly matched with sandeel populations during the day and was far higher in the 'high sandeel density' grid. Only at the finest scale examined, effort was concentrated at sandbanks but not significantly matched with local sandeel numbers. This suggested either insufficient knowledge among fishers or vessel maneuverability issues, possibly relating to high mobility of sandeels. Ten predatory fishes ( 8 'human consumption' species) preyed on sandeels, most notably whiting and lesser weever. Spatial comparisons showed that the predominant sandeel predators were whiting during the day and lesser weever at night. Tight predator-prey interdependencies were revealed: whiting and weever exhibited 'aggregative responses' to sandeels, and most predators consumed more sandeels in the 'high sandeel density' grid. On the Dogger Bank, sandeel fishing effort is concentrated when and where sandeels are most available, but also where these are extensively and locally preyed upon by at least 10 predatory fish species. Hence concerns that this industrial fishery may indirectly impact predatory fishes by depriving them of food might have some basis.
\end{abstract}

KEY WORDS: Ecosystem impacts · Sandeels · Industrial fishery · Predator-prey links · Diurnal movements $\cdot$ Fishing effort $\cdot$ Whiting $\cdot$ Lesser weever

\section{INTRODUCTION}

In marine ecosystems, small pelagic fish species can be crucial in channelling energy from lower planktonic trophic levels to predatory species at higher levels (Rice 1995). In the North Sea, localised concentrations of sandeels Ammodytes marinus provide high-energy food for a wide range of predators, from fishes (e.g. Reay 1970) to seabirds and marine mammals (Camphuysen 2005). However, sandeels are also exploited by a substantial industrial fishery for fishmeal and fish-oil, with annual landings ranging from 170000 to over 1 million $t$ (ICES 2007), higher than for any other North Sea species. Unsurprisingly, this fishery has been hotly debated since it first developed in the 1950s. Off Scotland and the Shetlands, a shortage of sandeels has been linked to the fishery, and, in turn, to low breeding success and declines in seabird colonies (Frederiksen et al. 2004, Poloczanska et al. 2004). However, most sandeel fishing occurs in more central parts of the North Sea that are relatively distant from seabird colonies. It is especially concentrated on the Dogger 
Bank, where between 26 and $62 \%$ of the entire North Sea sandeel catch was taken during 2000 to 2006 (ICES 2007). Here, sandeels are eaten by a variety of predatory fishes that in turn are important as 'human consumption' species, and that are crucial to demersal trawl fisheries of different European countries also active on the Dogger Bank (Jennings et al. 1999). These predatory fishes include such highly valued 'table species' as cod Gadus morhua, haddock Melanogrammus aeglefinus, mackerel Scomber scombrus and plaice Pleuronectes platessa (Reay 1970, Temming et al. 2004, Pinnegar et al. 2006). The potential negative consequences of the sandeel fishery for predatory fishes have concerned scientists and fishermen for some decades (e.g. Macer 1966), and UK trawlermen have recently accused the Danish sandeel fishery of driving them out of business by depriving predatory fishes of their natural diet (Anonymous 2003). Hence the extent to which industrial fishing on the Dogger Bank may locally deplete sandeels and impact predatory fish populations is of high priority for sustainable management of the North Sea ecosystem.

Sandeel activity patterns have strong seasonal and diurnal components. During autumn and winter they hibernate in the seabed, generally in coarse sands or fine gravel (Wright et al. 2000, Holland et al. 2005). During spring and summer they exhibit diurnal movements between the seafloor, where they bury themselves at night, and the water column, where they feed on plankton during daylight (Winslade 1974, Freeman et al. 2004). The horizontal extent of these movements is not fully known, although in closely related species the pelagic feeding locations may be several $\mathrm{km}$ away from the benthic resting sites (Kühlmann \& Karst 1967, Hobson 1986). Consequently, our first objective was to examine local-scale sandeel distributions in spring during day and night, and the possible horizontal extent of feeding migrations.

Sandeels feed in dense schools when in the water column and also tend to be highly localised at the benthic resting sites (Reay 1970). Such concentrated, local aggregations of fish are expected to be more prone to overexploitation and stock collapse than similar-sized, but widely distributed populations, especially if they can be located effectively by a fishery (Pitcher 1995, Mackinson et al. 1997). The sandeel fishery uses light and extensive, fine-meshed otter trawls (only 10 to $20 \mathrm{~mm}$ mesh in the codend) that are towed along ridges of sandbars or edges of sandbanks forming typical habitats of sandeels. The vessels fish for sandeels throughout spring and (early) summer, typically making 4 to $10 \mathrm{~d}$ fishing trips before unloading the catches at fishmeal factories (Hawkins et al. 1998). Our second objective was therefore to examine how tightly the distribution of sandeel fishing effort was matched spatially and temporally by that of sandeels, and hence the capability of fisheries to locally deplete the stock. Further, we examined whether effort distribution was more closely related to the day (in-water) or night (inseabed) distributions of sandeels.

Our third objective was to improve understanding of how 'crucial' sandeels are as prey for natural predators on the Dogger Bank during spring. Many demersal predators show a diurnal pattern in prey consumption, with foraging activity especially occurring at dawn and dusk (Hobson 1973, Jarre et al. 1991). Related to this, several authors have suggested that sandeels are most prone to predation when they leave the school and enter the seabed at dusk, or emerge from it at dawn (Kühlmann \& Karst 1967, Winslade 1974, Hobson 1986). Spatial distributions in such predators may be expected to match the night distributions of sandeels. On the other hand, some visually foraging, daylightdependent predators might target free-swimming sandeel schools (Pedersen 2000) in the water column; spatial patterns in this type of predators are expected to match the day distributions of sandeels.

\section{MATERIALS AND METHODS}

Study area. Biological data were collected during 3 surveys on the western Dogger Bank during 20 April to 4 May 2004, 6 to 17 May 2005 and 10 to 20 May 2006. Two survey grids were sampled, both about $650 \mathrm{~km}^{2}$ in area. Although separated by only $28 \mathrm{~km}$, these differed significantly in the intensity of sandeel fishing effort (Fig. 1). Grid $1\left(54^{\circ} 29^{\prime} \mathrm{N}, 1^{\circ} 13^{\prime} \mathrm{E}\right.$ to $54^{\circ} 40^{\prime} \mathrm{N}, 1^{\circ} 44^{\prime} \mathrm{E}$ ) was a heavily fished area encompassing part of the

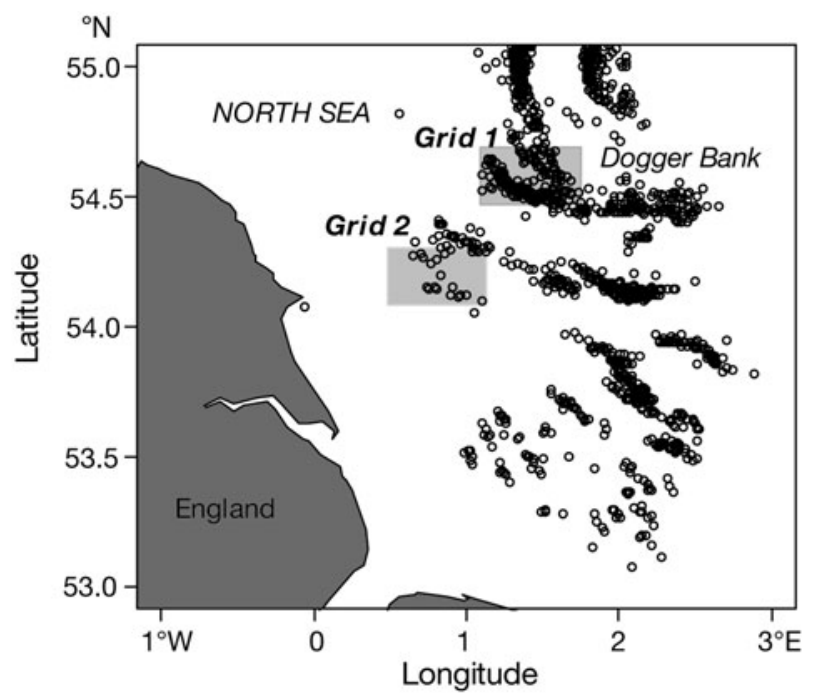

Fig. 1. Northeast England and the Dogger Bank region, with Grid 1 and Grid 2. O: distribution of sandeel fishing effort during the peak of the fishery in April-June 2005 (each point represents approximately $10 \mathrm{~h}$ fishing) 
'North West Riff' and southwestern edge of the Dogger Bank. Grid $2\left(54^{\circ} 6^{\prime} \mathrm{N}, 0^{\circ} 36^{\prime} \mathrm{E}\right.$ to $\left.54^{\circ} 17^{\prime} \mathrm{N}, 1^{\circ} 7^{\prime} \mathrm{E}\right)$ was a relatively unfished area to the southwest, including part of a bank named 'The Hills'. Sampling was carried out at 60 stations distributed over both grids (Fig. 2). Each of these was sampled for sandeels, as well as for potential predators of sandeels, within a $24 \mathrm{~h}$ period during day and night.

Night sandeel distributions. Within both grids, the distribution of sandeels buried in the seabed at night was examined. At each station, 10 min dredge tows were carried out between 22:00 and 04:00 h GMT using a modified French scallop dredge (width $1.2 \mathrm{~m}$ ). Catch-per-tow was converted to density (ind. $\mathrm{m}^{-2}$ ) by dividing the catch by the swept area, and including an $8 \%$ correction factor to account for the efficiency of the dredge for catching sandeels. This correction factor was based on previous estimates of sandeel dredge efficiency, ranging from 1.52 to $9.6 \%$, provided by Mackinson et al. (2005).

Day sandeel distributions. Acoustic methods were used to examine sandeel distributions in the water column during the day. Acoustic surveys started at dawn and ended around 11:00 h GMT; previous studies revealed that sandeels mostly forage during initial daylight hours (e.g. Freeman et al. 2004). In each survey grid, 10 parallel north-south transects were surveyed, each 27 nautical miles $(\mathrm{nm})$ long and $6.75 \mathrm{~nm}$ apart. These transects crossed the sampling stations

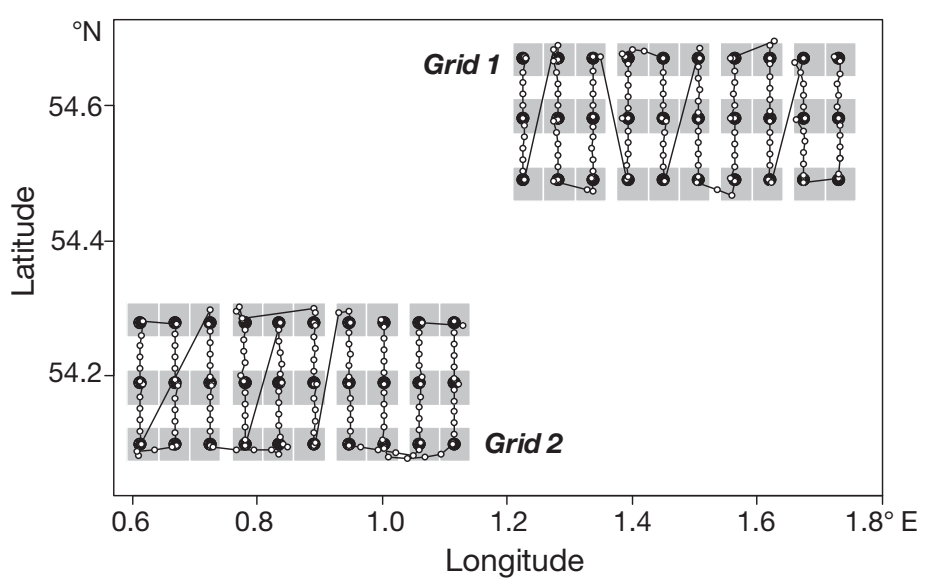

Fig. 2. Study grids 1 and 2, illustrating the survey design. Sampling stations where sandeels in the sediment were sampled by dredge at night and sandeel predators were sampled by trawl during the day; - : acoustics transect followed by the research vessel; $\mathrm{O}$ : locations for daytime acoustic biomass estimates, calculated for each nautical mile surveyed. Grey rectangles indicate areas of $0^{\circ} 3^{\prime}$ latitude by $0^{\circ} 3^{\prime}$ longitude surrounding each survey grid point, used in this study to 'match' trawl and dredge data (sampled by station) with acoustics (sampled along transects) and effort data (European Union Vessel Monitoring System database, accurate to $0^{\circ} 1^{\prime}$ latitude by $0^{\circ} 1^{\prime}$ longitude)
(Fig. 2). Acoustic signals at 38 and $120 \mathrm{kHz}$ were obtained using a stabilised Simrad EK60. The use of 2 frequencies allowed the distinction between sandeel schools, which show a stronger acoustic signal at $120 \mathrm{kHz}$, and schools of small clupeids which 'mark' much stronger at $38 \mathrm{kHz}$.

To estimate sandeel abundance, an integrated echo signal at $120 \mathrm{kHz}$ was calculated for all identified sandeel schools along each nm surveyed. Following Mackinson et al. (2005), we used a reference target strength (TS) at $120 \mathrm{kHz}$ of $-68.9 \mathrm{~dB}$ for a sandeel of $12.44 \mathrm{~cm}$ mean length. For a fish of $L \mathrm{~cm}$, this implies $\mathrm{TS}=20 \log (L)-90.8 \mathrm{~dB}$ (Mackinson et al. 2005). Utilising the reference target strength together with lengthfrequency data from the nighttime dredge samples of sandeels caught in the survey area, abundance estimates (ind. $\mathrm{km}^{-2}$ ) were derived by applying standard methods detailed in MacLennan \& Simmonds (1992) and Mackinson et al. (2005).

While data on night sandeel (and predator) distributions were only available by station, acoustic data were collected along transects (cf. Fig. 2). To facilitate comparisons, we converted the acoustic data to provide a measure of sandeel daytime abundance for each gridpoint. First, rectangles surrounding each grid point were delineated as $0^{\circ} 3^{\prime}$ latitude by $0^{\circ} 3^{\prime}$ longitude (Fig. 2). Next, sandeel day abundance was calculated by grid point as the mean of the acoustic abundance estimates that geographically fell within the corresponding rectangle (1 to 4 observations per gridpoint). Spatial rectangles of the given size were chosen to avoid overlap between neighbouring gridpoints while retaining reasonably detailed spatial resolution.

Within each grid, we compared day and night sandeel distributions statistically by calculating within-grid centres of gravity of sandeel distributions (indicative of the location of the highest sandeel abundances) by day and by night as weighted means with weighted variances of the latitudinal and longitudinal positions of stations (weighted by either day or night sandeel numbers observed by station). The latitudes and longitudes of the day and night centres of gravity of sandeel distributions were then compared using standard $t$-tests.

Sandeel fishing effort. Our analysis of sandeel fishing effort used data extracted from the European Union's Vessel Monitoring System (VMS) database, which monitors the positions of all EU-registered $>24 \mathrm{~m}$ fishing vessels (and since 2006 all $>15 \mathrm{~m}$ vessels). Extracted data included the positions for all Danish-registered fishing vessels between 2002 and 2006 within the wider Dogger Bank region $\left(53^{\circ} \mathrm{N}, 1^{\circ} \mathrm{W}\right.$ to $55.5^{\circ} \mathrm{N}, 3.5^{\circ} \mathrm{E}$, limited to UK waters), typically at $1 \mathrm{~h}$ intervals. Only data on sandeel fishing vessels were retained (so-called 'sandeelers', vessel length 26 to $57 \mathrm{~m}$; note that Dogger Bank sandeel catches are 
almost exclusively landed in Denmark). Identification of vessels as 'sandeelers' was based on online descriptions and photographs of vessels from www. fiskerforum.dk/kutterinfo. Data on engine power and tonnage were also obtained there, but as preliminary analyses yielded no obvious spatiotemporal patterns in power or tonnage of sandeelers, we quantified effort here directly as the number of hours fished by sandeelers.

The activity of fishing vessels was, based on vessel speed calculated from consecutive observations, categorised as either 'steaming' (speed $>4.5$ knots), 'trawling' (2 to 4.5 knots) or 'inactive' (<2 knots) (cf. Anonymous 1994, Hawkins et al. 1998). For analyses of spatial patterns of fishing effort, only VMS observations classified as 'trawling' and occurring during daylight hours were retained. We established whether an observation had occurred during darkness or daylight by (1) calculating the day length at the corresponding latitude and day using equations from Forsythe et al. (1995); and (2) calculating the times of sunrise and sunset from day length and longitude. In the restricted dataset, each VMS observation approximates $1 \mathrm{~h}$ fished.

We examined how closely spatial patterns of the number of hours fished were related to day or night distributions of sandeels as observed during surveys. However, the survey data had a coarser scale (by station) than the effort data (accurate to $0^{\circ} 1^{\prime}$ latitude/ longitude). To facilitate comparisons, we calculated a measure of local fishing effort for each of our survey grid points during (1) a shorter time window matching precisely the duration of each research survey; and (2) a longer time window including April-May of each survey year. For both time windows, local fishing effort by station was defined as the total number of hours fished within the spatial rectangle of $0^{\circ} 3^{\prime}$ latitude/ longitude surrounding each grid point; these spatial rectangles were equivalent to those used in the above-described daytime sandeel abundance estimates (Fig. 2).

We used linear mixed effects models to examine statistically how closely local fishing effort might be related to local day or night sandeel abundance (as measured at sampling stations during 3 surveys), and how it might differ between the 2 study grids. Models were of the form:

$$
\begin{aligned}
& \log (\text { h fished }+1) \approx \log \left(\text { sandeels }_{\text {day }}+1\right) \\
& +\log \left(\text { sandeels }_{\text {night }}+1\right)+\text { area }_{\text {yr }}
\end{aligned}
$$

where sandeel day and night abundances and area (Grid 1 or 2) were included as fixed effects, and survey year as a random effect.

‘Natural' predation on sandeels. In both study grids, we examined the stomach contents of a range of predatory fishes considered likely to prey upon sandeels. The fishes were sampled using a Granton trawl fitted with a $20 \mathrm{~mm}$ mesh liner in the codend. The horizontal and vertical opening of the net averaged 18 and $1.8 \mathrm{~m}$, respectively; the separation of the trawl doors averaged $41 \mathrm{~m}$. Tows were carried out for $20 \mathrm{~min}$ at each station between 11:00 and 19:00 h GMT each day. Catches were sorted and all individuals (or a subsample in case of very large numbers) per species were counted and their length measured. Catch-per-tow was converted to density (ind. $\mathrm{km}^{-2}$ ) by dividing the catch by the swept area (assuming $18 \mathrm{~m}$ net width). As we were lacking information on the selectivity or inefficiency of this gear for the predatory fish species examined, our figures on predator density only include the fish actually caught in the gear and should be considered as minimum estimates of true predator densities.

The reliance of predatory fish on sandeels was investigated at each station. Five fish from each $5 \mathrm{~cm}$ length class of a species were subsampled from the total catch, and their stomach contents were identified and weighed. Identity and digestion stage (on a 4 point scale) of all prey items and, where possible, individual prey length and weight were recorded. Where only a subsample of predators was stomach-sampled, the number of prey items recorded was raised to reflect those for the total numbers of predators in the catch. The raising factor was equal to the total number of a predator species and length class caught, divided by the subsampled number.

Table 1 provides an overview of 10 predator species from the 2 study grids where sandeel consumption was observed during any of the 3 survey years, along with the average number of predatory fish caught per $\mathrm{km}^{2}$ of swept area and the total number of stomach contents sampled. Unfortunately, stomach sampling of dab Limanda limanda was very limited in 2004 and 2005. Previously, 102 dab had been stomach-sampled at these sites and none had consumed sandeels; hence the species was initially not considered to be a sandeel predator. However, in 2006, stomachs of 71 dab (mainly larger fish) were sampled of which several contained sandeels. Given the small and non-random subsample and the species' high abundance, our consumption estimates for dab may be highly uncertain. Similarly, few stomach samples of lesser weever Echiichthys vipera were taken during the initial survey, although it was later found to be an important sandeel predator and this species was sampled extensively in 2005 and 2006.

We examined 4 predation measures for each predator species, signifying differing closeness of predatorprey relationships and how closely these were matched by the observed day and night distributions of sandeels. These predation measures were (1) total number of predators caught per $\mathrm{km}^{2}$ of swept area; 
(2) total number of sandeels eaten per $\mathrm{km}^{2}$ of swept area (by predators actually caught in the trawl); (3) number of sandeels eaten per individual predator, i.e. per capita sandeel consumption; and (4) sandeels as a fraction of all prey items consumed per individual predator, i.e. percentage of sandeel in predator diet. Notice that, while predation measures 1 and 2 are indicative of the importance of each predator species as a predator of sandeels, predation measures 3 and 4 are indicative of the importance of sandeels as food for the predators. Predation measures 3 and 4, if matched spatially with sandeel day or night distributions, would signify a close predator-prey link by indicating whether predators consume more sandeels where they occur in greater numbers. A strong predator-prey link would further be indicated by a 'match' between sandeels and the numbers of the predators themselves (predation measure 1), i.e. an 'aggregative response,' suggesting that local sandeel abundance may directly affect local predator numbers.

Statistically, predator-prey relationships were examined using linear mixed effects models (akin to Eq. 1). These described how closely each of predation measures 1 to 4 (local predator numbers, total sandeel consumption, per capita sandeel consumption, and \% sandeel in predator diet) might be related to local day or night sandeel abundance (as measured at sampling stations during 3 surveys), or might differ between the 2 study grids. Models were of the form:

$\log ($ predation measure +0.1$) \approx \log \left(\right.$ sandeels $\left._{\text {day }}+1\right)$

$$
+\log \left(\text { sandeels }_{\text {night }}+1\right)+\text { area }+ \text { year }
$$

including sandeel day and night numbers and area (Grid 1 or 2) as fixed effects, and survey year as a random effect.

\section{RESULTS}

\section{Sandeel distribution during day and night}

The 2 study grids differed markedly in sandeel abundance, both during the day and at night, as observed by acoustic methods and dredge sampling (Fig. 3). At night, mean sandeel abundance was 2.4 to 7 times higher in Grid 1 than in Grid 2 during the 3 study seasons (Mann-Whitney $U$-test, $U=25688, \mathrm{p}<0.00001$ ). The difference was also pronounced during daylight hours when very few sandeels were recorded in Grid 2 (none in the 2004 survey) $(U=11154, \mathrm{p}<0.01)$. Moreover, observed sandeel numbers were considerably higher in May 2005 and especially in May 2006 compared to April-May 2004 (Fig. 3) in terms of both day sandeel numbers (Kruskal-Wallis, $\chi^{2}=25.9, \mathrm{p}<0.00001$ ) and night sandeel numbers $\left(\chi^{2}=7.32, \mathrm{p}<0.05\right)$.

Table 1. Abundances of all predator species where sandeel consumption was observed by study grid and year, with the mean numbers caught per $\mathrm{km}^{2}$ of swept area (averaged by station) and total sample sizes of fish where stomach contents were examined. Species shown in decreasing order of overall abundance

\begin{tabular}{|c|c|c|c|c|c|c|c|c|c|c|c|c|}
\hline \multirow{3}{*}{ Predator species } & \multicolumn{6}{|c|}{ Mean number caught per $\mathrm{km}^{2}$ swept area } & \multicolumn{6}{|c|}{ Total number of stomach content samples } \\
\hline & \multicolumn{3}{|c|}{ Grid 1} & \multicolumn{3}{|c|}{ Grid 2} & \multicolumn{3}{|c|}{ Grid 1} & \multicolumn{3}{|c|}{ Grid 2} \\
\hline & 2004 & 2005 & 2006 & 2004 & 2005 & 2006 & 2004 & 2005 & 2006 & 2004 & 2005 & 2006 \\
\hline \multicolumn{13}{|l|}{ Dab } \\
\hline Limanda limanda & 6644 & 6047 & 4796 & 3159 & 3104 & 1405 & 0 & 0 & 51 & 9 & 0 & 20 \\
\hline \multicolumn{13}{|l|}{ Whiting } \\
\hline Merlangius merlangus & 980 & 803 & 778 & 1428 & 2941 & 1879 & 407 & 307 & 376 & 219 & 447 & 473 \\
\hline \multicolumn{13}{|l|}{ Lesser weever } \\
\hline Echiichthys vipera & 2987 & 1861 & 1677 & 139 & 644 & 418 & 0 & 230 & 238 & 4 & 171 & 171 \\
\hline \multicolumn{13}{|l|}{ Grey gurnard } \\
\hline $\begin{array}{l}\text { Eutrigla gurnardus } \\
\text { Plaice }\end{array}$ & 252 & 339 & 400 & 696 & 914 & 952 & 222 & 348 & 327 & 207 & 364 & 392 \\
\hline Pleuronectes platessa & 129 & 28 & 24 & 190 & 103 & 65 & 106 & 43 & 44 & 50 & 97 & 115 \\
\hline \multicolumn{13}{|c|}{ Haddock } \\
\hline $\begin{array}{l}\text { Melanogrammus aeglefinus } \\
\text { Mackerel }\end{array}$ & Is 63 & 9 & 54 & 67 & 107 & 105 & 72 & 15 & 61 & 66 & 91 & 109 \\
\hline Scomber scombrus & 0 & 93 & 8 & 4 & 130 & 60 & 0 & 63 & 12 & 0 & 70 & 78 \\
\hline \multicolumn{13}{|l|}{ Greater sandeel } \\
\hline Hyperoplus lanceolatus & 1 & 58 & 8 & 1 & 9 & 9 & 0 & 58 & 15 & 0 & 12 & 12 \\
\hline \multicolumn{13}{|l|}{ Cod } \\
\hline Gadus morhua & 22 & 1 & 15 & 7 & 1 & 9 & 26 & 0 & 26 & 3 & 1 & 15 \\
\hline \multicolumn{13}{|l|}{ Turbot } \\
\hline Psetta maxima & 0 & 0 & 0 & 0 & 1 & 1 & 0 & 0 & 0 & 0 & 0 & 1 \\
\hline All predators & 11078 & 9239 & 7760 & 5691 & 7954 & 4903 & 833 & 1064 & 1150 & 558 & 1253 & 1386 \\
\hline
\end{tabular}




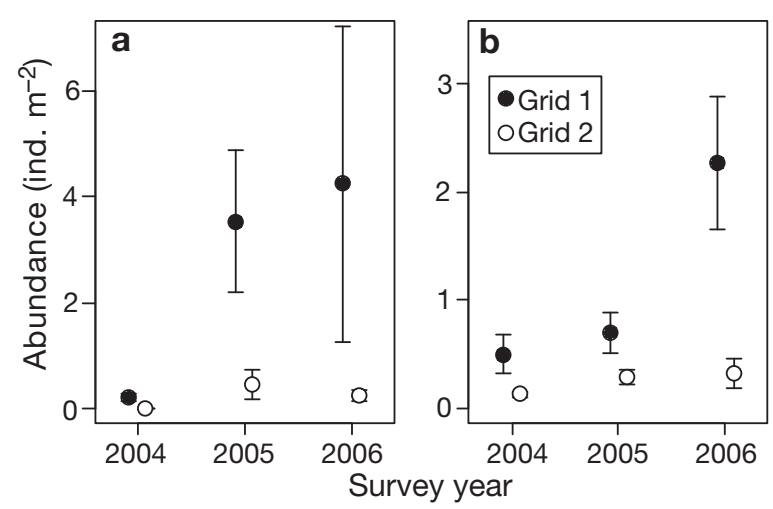

Fig. 3. Ammodytes marinus. Sandeel abundance compared between study grids and years, as observed (a) during daytime (in the water column) and (b) at night (in the seabed). Means $\pm 1 \mathrm{SE}$ of values by station are shown

Sandeels were also highly localised within study grids (Fig. 4). Often, within-grid distributions differed notably between day and night, in line with horizontal diurnal movement patterns. This was especially the case in Grid 1, except during April-May 2004 when very few sandeels were observed acoustically and positions (longitudinal and latitudinal) of centres of gravity of sandeel distributions did not differ significantly between day and night (longitude: $t=0.424, \mathrm{p}=$ 0.673 , latitude: $t=0.871, \mathrm{p}=0.387$ ) (Fig. 4a). However, horizontal diurnal movements in Grid 1 appeared prominent in May 2005 and 2006 when the night (seabed) sandeel distributions were concentrated in the (shallower) central and northeastern parts, whereas the day (in-water) distributions were concentrated in the (deeper) southwestern part. Within Grid 1, the distances between the centres of gravity of day and night distributions amounted to $15.3 \mathrm{~km}$ in May 2005 (Fig. 4b), and $11.7 \mathrm{~km}$ in May 2006 (Fig. 4c). In both years, the position of the centres of gravity of sandeel distribution differed significantly between day and night (2005, longitude: $t=-4.79, \mathrm{p}<0.0001$, latitude $t=$ $-4.71, \mathrm{p}<0.0001$; 2006, longitude: $t=-2.93, \mathrm{p}<0.005$, latitude $t=-5.00, \mathrm{p}<0.0001$ ). It is important to note that only data from within the sampling grids were available, and that within-grid day/night distribution shifts cannot be directly interpreted as representing the true extent of horizontal diurnal movements, which might include relocation to areas outside the grids.

Horizontal diurnal movements were less evident for Grid 2. Here, centres of gravity of day and night distributions were only separated by $5.4 \mathrm{~km}$ in May 2005, and $4.7 \mathrm{~km}$ in May 2006 (and no sandeels observed by day in April-May 2004). Within Grid 2, longitudinal (but not latitudinal) positions of centres of gravity of sandeel distributions did differ significantly between day and night in 2005 (longitude $t=2.13, \mathrm{p}<0.05$, latitude $t=-1.10, \mathrm{p}=0.276$ ), but there were no such differences in 2006 (longitude $t=-1.09, \mathrm{p}=0.285$, latitude $t=-1.36, \mathrm{p}=0.181$ ). Nevertheless, night (seabed) distributions were concentrated in the shallower central part, while sandeels were more in the periphery of the grid during daytime. In both grids, distributions tended to be more localised and variable during the day than at night, which was related to the clustering of sandeels in schools during daytime.

\section{Sandeel fishing effort}

Movements by 'sandeelers' in the wider Dogger Bank region showed distinct differences between daylight and darkness hours (Fig. 5). Vessel speeds characteristic of trawling ( 2 to 4.5 knots) occurred far more frequently during the day than at night, consistent with
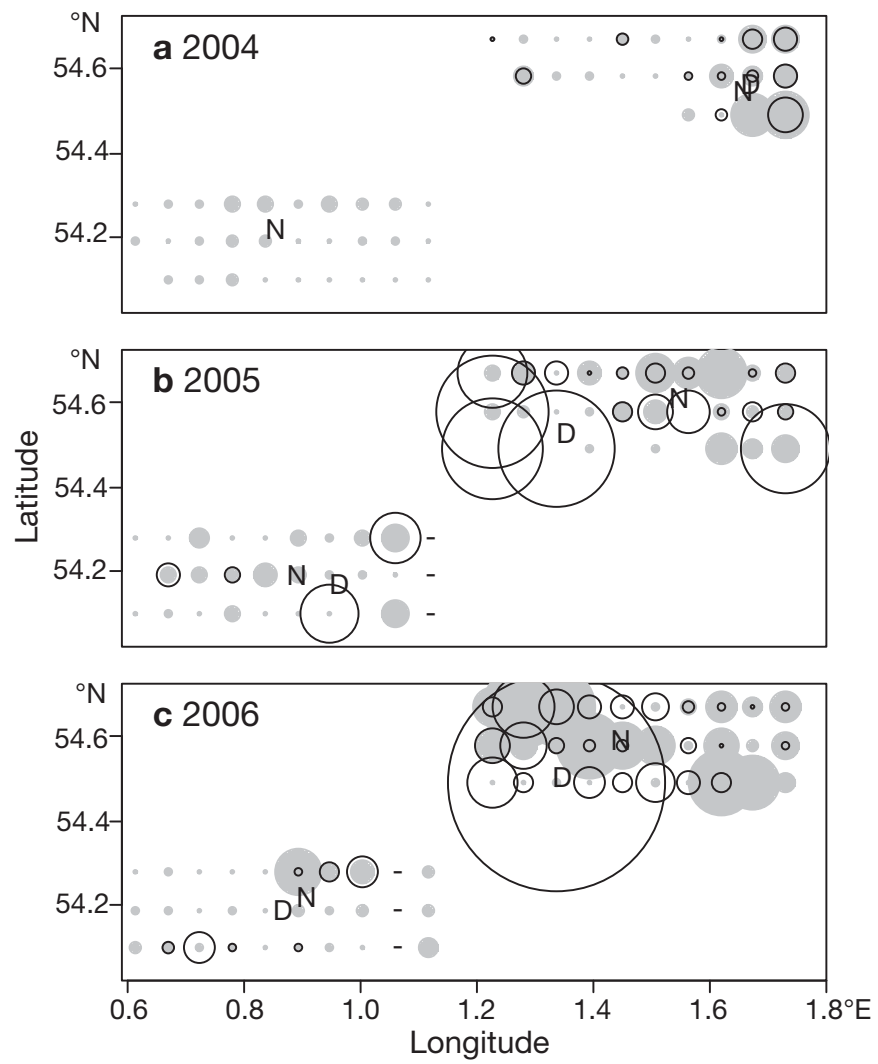

Fig. 4. Ammodytes marinus. Comparison of day and night distribution of sandeels in the 2 study grids, as observed during (a) April-May 2004, (b) May 2005, and (c) May 2006. Area size of grey symbols proportional to night numbers in the seabed, and of open symbols proportional to day numbers in the water column $\left(1000 \mathrm{~m}^{-2}\right.$; day and night numbers equally scaled). (-): Grid points not surveyed in the given year. ' $\mathrm{D}$ ' and 'N' mark the within-grid centres of gravity of sandeel distribution during day (D) and night (N), respectively 


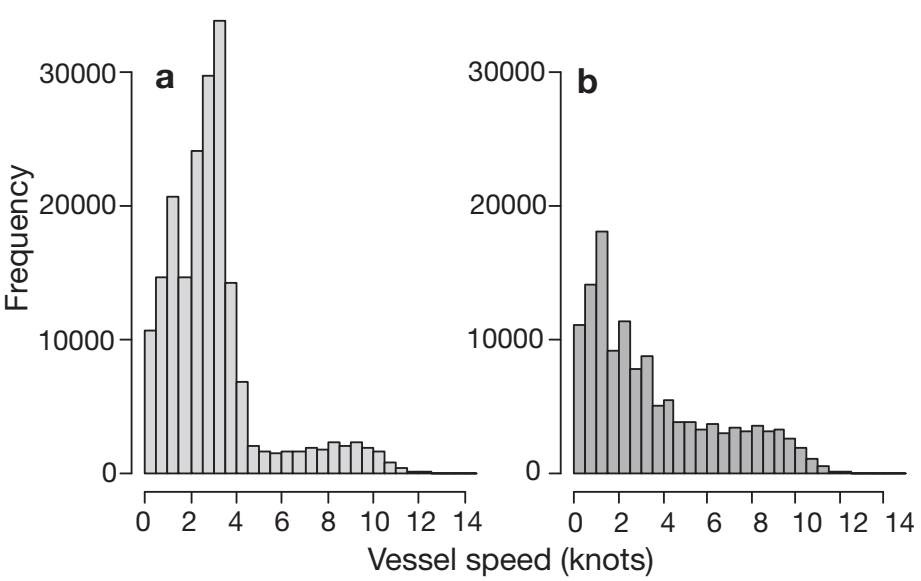

Fig. 5. Frequency distributions of vessel speeds in VMS observations of 107 sandeelers during (a) day and (b) night

targeting free-swimming sandeel schools during daylight. In contrast, vessel speeds characteristic of steaming (>4.5 knots) occurred more commonly at night, implying use of darkness hours to move between fishing grounds. There were no day/night differences in occurrence of very low vessel speeds ( $<2$ knots), which are indicative of inactivity.

Sandeel fishing effort differed substantially between both grids (Fig. 6) and, averaged over 2002 to 2006, was over 40 times higher in Grid 1 than in Grid 2 (mean $\pm \mathrm{SE}, 2310 \pm 297$ and $56 \pm 32 \mathrm{~h}$, respectively). It was from March to June that far greater effort occurred in Grid 1; in other months, effort was negligible in either grid (Fig. 6). This was in accordance with seasonality of sandeels in the water column and with far higher sandeel numbers observed in Grid 1 during our surveys.

At a finer scale, effort distribution within grids was apparently not matched closely with sandeel distribu-

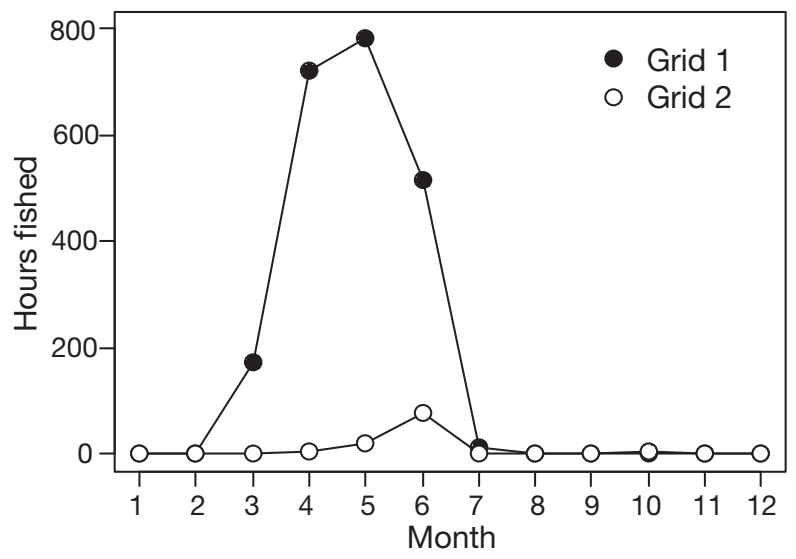

Fig. 6. Monthly sandeel fishing effort (hours fished by Danish sandeelers, averaged over January 2002 to August 2006) expended in Grids 1 and 2 tions as measured during our surveys (Fig. 7). Sandeel fishing effort was highly localised, occurring in a series of bands running from WNW to ESE. These patches of concentrated effort generally matched topographical features, particularly the edges of banks and sandy ridges, but they did not obviously coincide with survey stations where high sandeel numbers were recorded, whether during day (acoustics) or night (dredge). There was no indication that effort distribution was better matched with observed day than night sandeel distributions. Rather, the centre of gravity of effort distribution
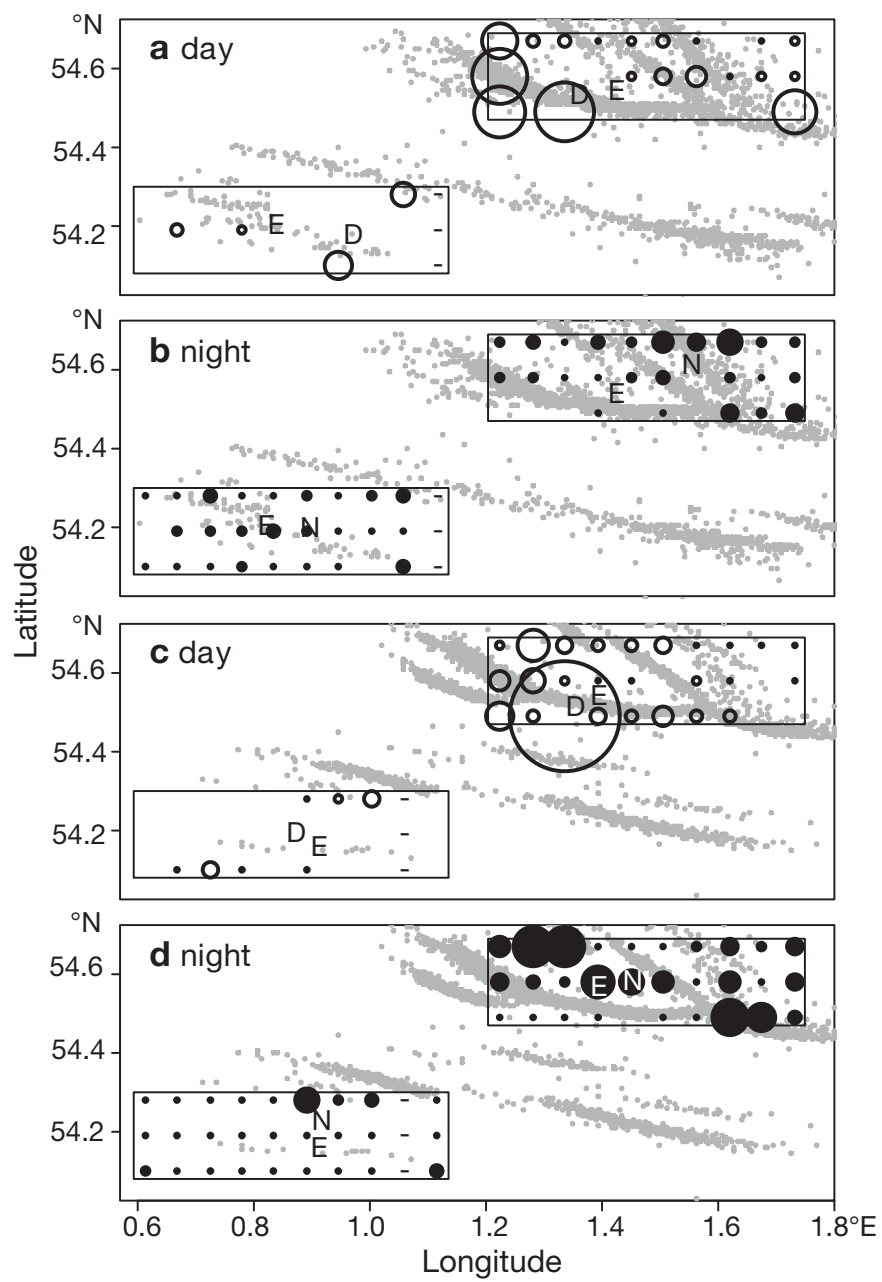

Fig. 7. Ammodytes marinus. Fine-scale distribution of sandeel fishing effort compared with day and night distributions of sandeels (study grids indicated by rectangles). Small grey dots indicate approximately $1 \mathrm{~h}$ fished by Danish 'sandeelers' during (a,b) April-May 2005 and (c,d) April-May 2006. Area size of open symbols in (a) and (c) proportional to day sandeel numbers observed acoustically during our May 2005 and 2006 surveys, respectively. Area size of filled symbols in (b) and (d) proportional to night sandeel numbers sampled by dredge during the same surveys. (-): Unsampled stations; (E, D, N): within-grid centres of gravity of fishing effort and day and night sandeel distributions 
Table 2. Results from linear mixed effects models on relationships between local sandeel abundance (day or night) in the 2 study grids (as measured at sampling stations during 3 surveys) and local fishing effort. Effort quantified as number of hours fished in rectangles of $0^{\circ} 3^{\prime}$ latitude by $0^{\circ} 3^{\prime}$ longitude surrounding each station during a short (duration of each survey only) and a longer time window (April-May of each survey year). See Eq. (1) for model description. Bold type indicates coefficients ( \pm SE) significantly different from $0(\mathrm{p}<0.05)$. Note that, in the area comparison, the positive coefficient implies higher effort in the 'high sandeel abundance' Grid 1

\begin{tabular}{|c|c|c|c|c|c|c|}
\hline \multirow{3}{*}{$\begin{array}{l}\text { Dependent } \\
\text { variable: Local } \\
\text { fishing effort }\end{array}$} & \multicolumn{6}{|c|}{ - Independent variables - } \\
\hline & \multicolumn{2}{|c|}{ Day abundance } & \multicolumn{2}{|c|}{ Night abundance } & \multicolumn{2}{|c|}{ Area effect (Grid 1) } \\
\hline & Coefficient $\pm \mathrm{SE}$ & $\mathrm{p}$ & Coefficient $\pm \mathrm{SE}$ & $\mathrm{p}$ & Coefficient \pm SE & $\mathrm{p}$ \\
\hline Period of survey & $0.008 \pm 0.026$ & 0.762 & $-0.036 \pm 0.032$ & 0.262 & $1.01 \pm 0.17$ & $<0.0001$ \\
\hline $\begin{array}{l}\text { April-May } \\
\text { of survey year }\end{array}$ & $-0.024 \pm 0.035$ & 0.489 & $-0.071 \pm 0.045$ & 0.119 & $2.13 \pm 0.23$ & $<0.0001$ \\
\hline
\end{tabular}

within Grid 1 tended to be intermediate between those for sandeels during day and night (Fig. 7).

This was confirmed statistically by linear mixed effects models on relationships between day or night sandeel abundances observed at stations in both grids, and local fishing effort (Table 2). Effort was quantified as the number of hours fished by sandeelers in rectangles of $0^{\circ} 3^{\prime}$ latitude by $0^{\circ} 3^{\prime}$ longitude surrounding each station, either during a short (duration of each survey only) or longer time window (April-May of each survey year). Indeed, the difference in effort between study grids was highly significant for both time windows $(p<0.0001)$. After the grid effect was accounted for, no significant relationships $(p>0.1)$ were detected between finer-scale (within-grid) day or night sandeel distributions and local fishing effort (regardless of time window). There were no indications that effort was more closely linked to observed day rather than night sandeel distributions. Overall, these results suggest that fine-scale (within-grid) distribution of sandeel fishing effort was largely motivated by topographical features, although, at a somewhat coarser scale (between-grids), there was a highly significant match with sandeel abundance.

\section{Sandeel predators}

Sandeels were found in the stomachs of 10 predator species (Table 1). Four of the predators could be considered 'abundant', being present in 95 to $99 \%$ of all trawl hauls at average densities of about 500 to 5000 fish $\mathrm{km}^{-2}$ of swept area; these were dab Limanda limanda, whiting Merlangius merlangus, lesser weever Echiichthys vipera and grey gurnard Eutrigla gurnardus. Together, these included $97 \%$ of all predators. Five 'moderately common' species were present in 20 to $84 \%$ of trawl hauls at about 10 to 100 fish $\mathrm{km}^{-2}$ of swept area. These were plaice Pleuronectes platessa, haddock Melanogrammus aeglefinus, mackerel Scomber scombrus, greater sandeel Hyperoplus

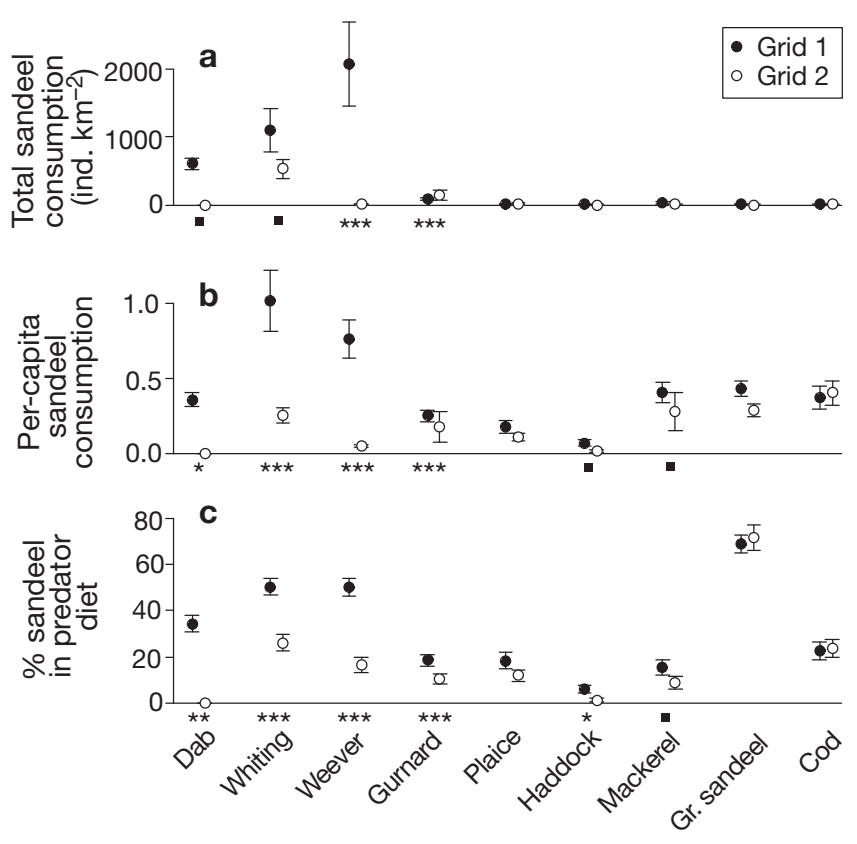

Fig. 8. Ammodytes marinus. Three measures of predation by 9 predator species, compared between Grid 1 ('high sandeel abundance') and Grid 2 ('low sandeel abundance'). Measures of predation include (a) total number of sandeel consumed $\mathrm{km}^{-2}$, (b) per capita consumption of sandeel, and (c) \% sandeel in the diet of predators. Means \pm 1 SE are shown. Significant differences between years marked with ${ }^{* * *} \mathrm{p}<$ $0.001,{ }^{* *} \mathrm{p}<0.01,{ }^{*} \mathrm{p}<0.05,-\mathrm{p}<0.1$ (ANOVA, accounting for interannual differences). See Table 1 for number of fish stomachs examined

lanceolatus and cod Gadus morhua. The tenth species, turbot Psetta maxima, was only caught twice during the 3 surveys, although the single stomach-sampled fish contained 3 sandeels.

The total sandeel consumption (Fig. 8a) was dominated by 2 of the 'abundant' predators, whiting and lesser weever, which together consumed $80 \%$ (35 and $45 \%$, respectively) of all sandeels eaten per $\mathrm{km}^{2}$ by these 10 species (Fig. 8a). Whiting was most common in Grid 2 and the dominant sandeel predator here 
(73\% of all sandeels consumed). Lesser weever was most common in Grid 1, where it dominated sandeel consumption (53\% of all sandeels consumed). Grey gurnard was relatively unimportant in Grid 1 ( $2 \%$ of all sandeels consumed), but in Grid 2, where it was more abundant, it was the second-most important sandeel predator ( $20 \%$ of all sandeels consumed). Sandeel consumption by dab remained unclear, owing to data being limited to mainly larger fish in 2006; stomachs of $29 \%$ of dab in Grid 1 contained sandeels (none in Grid 2). Given the high abundance of dab, this could imply extensive sandeel predation in Grid 1, although our consumption estimate (610 sandeels consumed $\mathrm{km}^{-2}$ ) (Fig. 8a) is highly uncertain given the small nonrandom subsample. Total sandeel consumption by the remaining species plaice, haddock, mackerel, greater sandeel, cod and turbot, remained relatively unimportant owing to their low numbers, and for the 6 species combined was only $2 \%$ of all sandeels consumed.

Both the total and per capita sandeel consumption by predators and the percentage of sandeels in predator diets differed markedly between both study grids (Fig. 8), reflecting area differences in sandeel abundances (cf. Fig. 3). Seven out of 9 predator species recorded in both areas consumed more sandeels in total in Grid 1 ('high sandeel density') than in Grid 2 ('low sandeel density'); the 2 exceptions were grey gurnard and plaice, themselves more abundant in Grid 2. Similarly, 8 out of 9 predator species on average showed higher per capita sandeel consumption, and 7 species had higher percentages of sandeels in their diets in Grid 1 compared to Grid 2; the exception was cod, where data were very limited.

Among all predators, lesser weever and whiting showed the highest per capita sandeel consumption (0.83 and 0.57 sandeel per predator, respectively) (Fig. 8b) and some of the highest percentages of sandeels in their diet (35 and 39\%, respectively) (Fig. 8c); hence both high numbers and high sandeel consumption contributed to their dominance as sandeel predators. Among the 'moderately common' predators, haddock consumed sandeels relatively rarely (0.03 sandeel per predator), sandeels comprising $<3 \%$ of the diet. By comparison, sandeels were important in the diet of plaice $(0.14$ sandeel per predator; $15 \%$ of diet), mackerel (0.32 sandeel per predator; $11 \%$ of diet), cod (0.38 sandeel per predator; $23 \%$ of diet) and, notably, greater sandeel. This was, among all predators, the species that consumed (lesser) sandeels most exclusively: the smaller species comprised $70 \%$ of the diet of its larger relative $(0.38$ sandeel per predator) (Fig. 8b,c).

Between-year differences in sandeel numbers (Fig. 3) were similar to the area differences (Fig. 8), reflected in sandeels consumed (Fig. 9). Generally, the total and per capita sandeel consumption and percentage sandeel in predator diet tended to be lowest in April-May 2004, when sandeel numbers were lowest, and highest in either May 2005 or 2006, depending on the predator species. However, for many of the predator species (notably those for which our sample sizes were small), interannual differences were non-significant. Plaice deviated from other species in showing highest sandeel consumption in the 'low sandeel' year 2004.

For the dominating sandeel predators whiting, lesser weever, and grey gurnard we examined to what extent day or night spatial distributions of sandeels in the 2 study grids matched spatial distributions of predator numbers, sandeel consumption, and percentage sandeel in predator diet (Fig. 10). The strengths of relationships were examined statistically by linear mixed effects models (Table 3).

Lesser weever were most tightly linked to local sandeel numbers (Fig. 10g-i). In the 'high sandeel' Grid 1 , they showed significantly higher total sandeel consumption, per capita sandeel consumption, and percentage sandeel in diet than in Grid 2 (Table 3, p < 0.002),
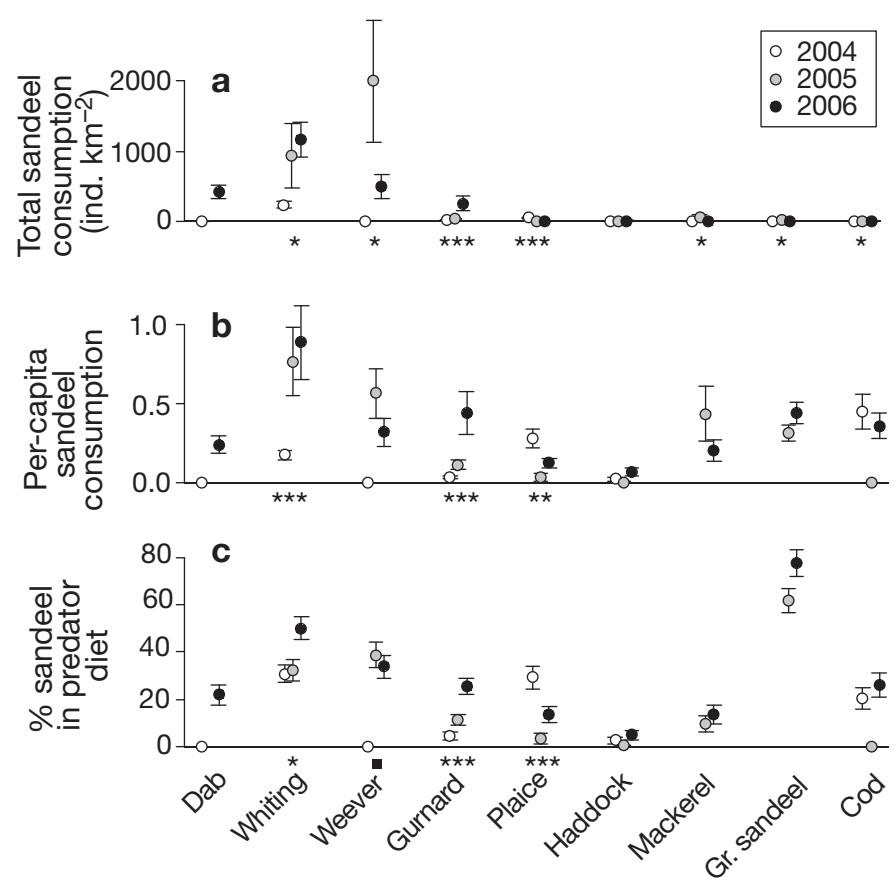

Fig. 9. Ammodytes marinus. Three measures of predation by 9 predator species, compared between survey years of low (2004) and high $(2005,2006)$ sandeel abundance in both grids combined. Measures of predation include (a) total sandeel consumed $\mathrm{km}^{-2}$, (b) per-capita sandeel consumption, and (c) $\%$ sandeel in the diet of predators. Means $\pm 1 \mathrm{SE}$ are shown. Significant differences between years marked with ${ }^{* * *} \mathrm{p}<$ $0.001,{ }^{* *} \mathrm{p}<0.01,{ }^{*} \mathrm{p}<0.05, \mathbf{m}: \mathrm{p}<0.1$ (ANOVA, accounting for differences between study grids). See Table 1 for number of fish stomachs examined 

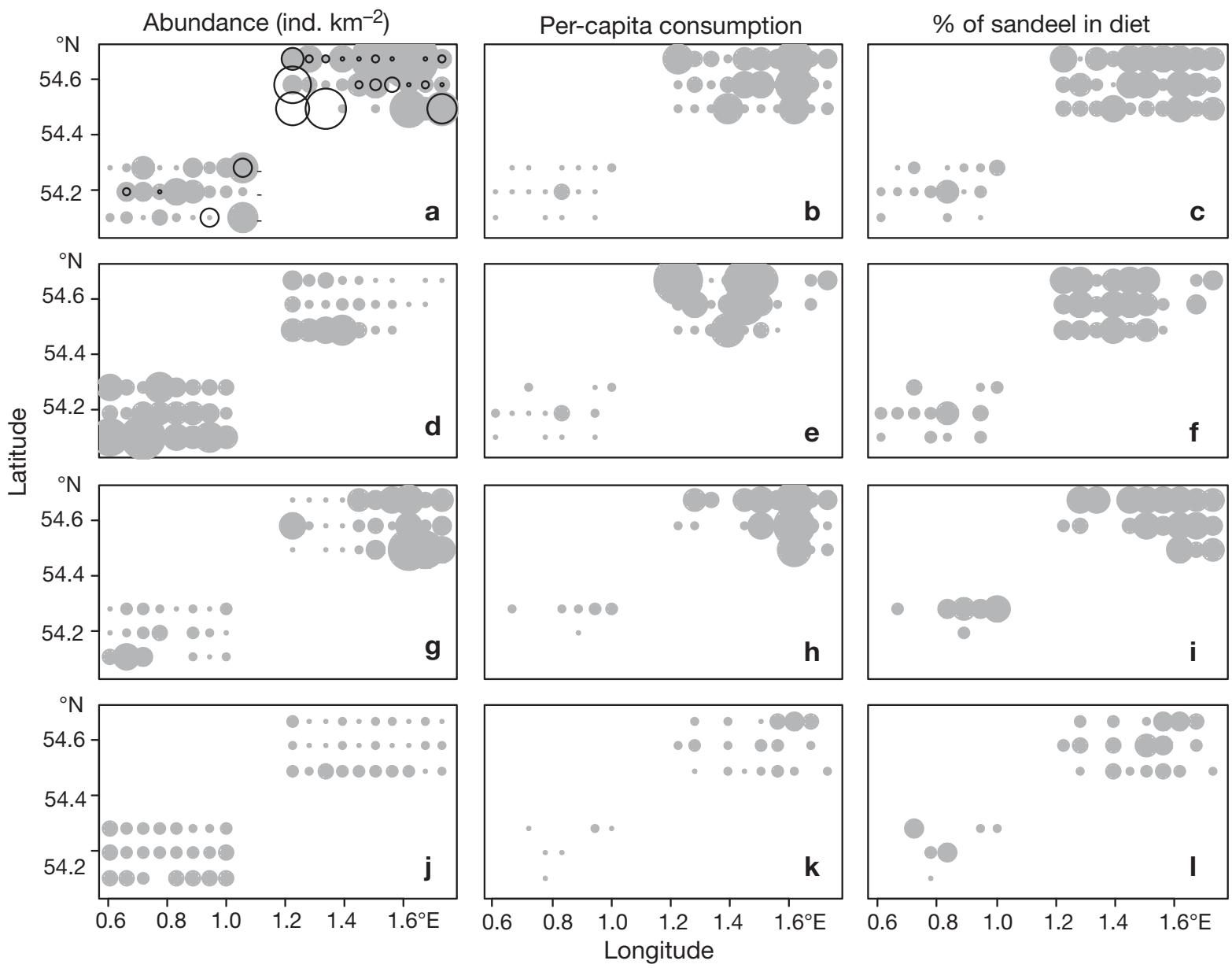

Fig. 10. Sandeel Ammodytes marinus and predators, including whiting Merlangius merlangus, lesser weever Echiichthys vipera and gurnard Eutrigla gurnardus. Comparison of the spatial distribution during May 2005 of (a) sandeels during day (open circles) and night (grey circles) with that of (b) per capita consumption of sandeel and (c) \% sandeel in the diet of all predatory fish species (excluding dab). Distribution, per capita sandeel consumption, and \% sandeel in diet during May 2005 of (d-f) whiting,

$(g-i)$ lesser weever, and (j-l) grey gurnard. Scales consistent among graphs in the same column, except (a)

and near-significantly higher abundances $(\mathrm{p}=0.056)$. Weever numbers, total and per capita sandeel eaten, and percentage sandeel in diet within grids were all significantly and positively related with local nighttime sandeel numbers $(\mathrm{p}<0.05)$, but there was no significant relationship with day sandeel numbers $(p>0.3)$.

Whiting (Fig. 10d-f) were reasonably tightly linked to sandeels, although less so than weevers, as they were, unexpectedly, less abundant in the 'high sandeel' Grid 1 than in Grid 2 ( $\mathrm{p}<0.0001)$ (Table 3). Whiting did, however, show higher per capita sandeel consumption in this grid ( $p=0.006)$, as well as a higher percentage sandeel in the diet $(p=0.014)$. Importantly, within-grid whiting numbers and total and per capita sandeel eaten were significantly positively related to local daytime sandeel numbers $(\mathrm{p}<0.05)$. Conversely, and unlike weevers, there were no positive links with night sandeel numbers; within grids, whiting numbers were negatively associ- ated with night sandeel numbers $(\mathrm{p}<0.0001)$, and there were no significant relationships with sandeel consumption measures by whiting ( $p>0.05)$.

Of the 3 species, grey gurnard showed relatively weaker links to sandeels (Figs. 10j-1), as their numbers were lower in the 'high sandeel' Grid 1 ( $p<0.0001)$ (Table 3). Within grids, abundances of grey gurnard were negatively related to night $(p=0.008)$, but not day ( $\mathrm{p}=0.673$ ), sandeel abundances (Table 3). However, grey gurnard showed a higher total sandeel consumption ( $p=0.002)$, higher per capita sandeel consumption $(\mathrm{p}=0.0009)$, and higher percentage sandeel in diet $(\mathrm{p}=$ 0.002) in the 'high' compared to the 'low' sandeel grid, indicating the importance of sandeel as prey for this species. Overall, these results suggest that sandeels were mainly preyed upon by whiting during the day and by lesser weever at night (or at dawn or dusk); it is unclear when predation by grey gurnard occurred. 
Table 3. Results from linear mixed effects models, describing how the 4 measures of sandeel predation by whiting, lesser weever and grey gurnard related to day or night sandeel numbers observed at stations, and/or differed between study grids. Predation measures include local predator numbers, total sandeel consumption, per capita sandeel consumption, and percentage sandeel in predator diet. See Eq. (2) for model description. Bold type indicates coefficients $( \pm S E)$ significantly different from 0 ( $p<0.05)$. Note that, in the area comparison, a positive coefficient implies higher predator numbers or higher sandeel consumption in the 'high sandeel abundance' Grid 1

\begin{tabular}{|c|c|c|c|c|c|c|}
\hline \multirow{3}{*}{$\begin{array}{l}\text { Dependent } \\
\text { variable }\end{array}$} & \multirow{2}{*}{\multicolumn{2}{|c|}{ Day sandeel abundance }} & \multirow{2}{*}{\multicolumn{2}{|c|}{$\begin{array}{l}\text { - Independent variables } \\
\text { Night sandeel abundance }\end{array}$}} & \multirow{2}{*}{\multicolumn{2}{|c|}{ Area effect (Grid 1) }} \\
\hline & & & & & & \\
\hline & Coefficient \pm SE & $\mathrm{p}$ & Coefficient \pm SE & $\mathrm{p}$ & Coefficient $\pm \mathrm{SE}$ & $\mathrm{p}$ \\
\hline \multicolumn{7}{|l|}{ Whiting } \\
\hline Number & $0.23 \pm 0.06$ & 0.0001 & $-0.42 \pm 0.07$ & $<0.0001$ & $-2.60 \pm 0.37$ & $<0.0001$ \\
\hline Total sandeel consumption & $0.38 \pm 0.11$ & 0.0006 & $-0.25 \pm 0.14$ & 0.076 & $0.02 \pm 0.74$ & 0.979 \\
\hline Per capita sandeel consumption & $0.08 \pm 0.03$ & 0.019 & $0.01 \pm 0.04$ & 0.705 & $0.57 \pm 0.20$ & 0.006 \\
\hline$\%$ sandeel in predator diet & $0.12 \pm 0.08$ & 0.136 & $0.08 \pm 0.10$ & 0.435 & $1.32 \pm 0.53$ & 0.014 \\
\hline \multicolumn{7}{|l|}{ Lesser weever } \\
\hline Number & $-0.06 \pm 0.08$ & 0.466 & $0.34 \pm 0.10$ & 0.001 & $1.01 \pm 0.52$ & 0.056 \\
\hline Total sandeel consumption & $-0.07 \pm 0.11$ & 0.538 & $0.68 \pm 0.14$ & $<0.0001$ & $3.67 \pm 0.77$ & $<0.0001$ \\
\hline Per capita sandeel consumption & $n-0.01 \pm 0.03$ & 0.859 & $0.14 \pm 0.04$ & 0.0007 & $0.98 \pm 0.22$ & $<0.0001$ \\
\hline$\%$ sandeel in predator diet & $0.04 \pm 0.10$ & 0.699 & $0.42 \pm 0.14$ & 0.003 & $2.30 \pm 0.72$ & 0.002 \\
\hline \multicolumn{7}{|l|}{ Grey gurnard } \\
\hline Number & $-0.01 \pm 0.03$ & 0.673 & $-0.10 \pm 0.04$ & 0.008 & $-0.77 \pm 0.19$ & 0.0001 \\
\hline Total sandeel consumption & $-0.07 \pm 0.09$ & 0.416 & $0.15 \pm 0.11$ & 0.173 & $1.79 \pm 0.56$ & 0.002 \\
\hline Per capita sandeel consumption & n $\quad 0.01 \pm 0.02$ & 0.777 & $0.04 \pm 0.03$ & 0.096 & $0.46 \pm 0.13$ & 0.0009 \\
\hline$\%$ sandeel in predator diet & $-0.02 \pm 0.07$ & 0.725 & $0.12 \pm 0.09$ & 0.178 & $1.42 \pm 0.45$ & 0.002 \\
\hline
\end{tabular}

\section{DISCUSSION}

The Dogger Bank in the North Sea is one of the world's prime industrial fishing grounds. The present study provides new quantitative insight into the extent of the diurnal feeding migrations of sandeels on the bank, and how sandeels are targeted by 2 of their main sources of predation: the 'human' sandeel fishery and their 'natural' piscine predators.

\section{Sandeel day/night distributions}

Although day/night migrations of sandeels have long been known to exist (e.g. Macer 1966, Kühlmann \& Karst 1967, Hobson 1986), little quantitative information was available on their horizontal extent. Results from the present study indicate that sandeel distributions observed during the day (while in the water column) differed markedly from those at night (while in the seabed), at least in spring 2005 and 2006. In 2004, horizontal diurnal movements were not apparent, but we suspect that, due to the earlier timing of this survey, the main feeding season for sandeels was missed; furthermore, sandeel numbers were generally very low in our study area in 2004, as they were throughout the North Sea (e.g. Frederiksen et al. 2005).

In accordance with previous studies (Kühlmann \& Karst 1967, Hobson 1986), sandeels moved between shallower grounds at night and deeper waters during the day. Night sandeel locations were often characterised by medium to fine sands, previously described as preferred sandeel burying habitats (Wright et al. 2000, Holland et al. 2005). The deeper waters where sandeel schools tended to occur during the day have been postulated to contain higher zooplankton productivity during the summer months (van der Kooij et al. 2008). Hence, sandeel diurnal movements are likely motivated by local distributions of suitable nighttime shelter and daytime feeding opportunities (Reay 1970).

Notably, the scale of diurnal horizontal movements was more extensive than previously recorded, especially within Grid 1 where sandeel densities were high. Earlier studies on diurnal movements in related Ammodytes species reported a scale of about 0.2 to several $\mathrm{km}$ (Kühlmann \& Karst 1967, Hobson 1986). In our study, however, the centres of gravity of day and night distributions within Grid 1 differed by no less than $15.3 \mathrm{~km}$ in May 2005 and 11.7 km in May 2006. Day/night differences in spatial distributions represent aggregate data and, unlike tagging data, cannot be directly interpreted as representing individual movements. Nevertheless, these patterns suggest fairly impressive movements, given the small size of sandeel and their lack of a swim bladder. It is likely that sandeel Ammodytes marinus make use of tidal movements, given that observed swimming speeds in the smaller relative Ammodytes tobianus were only about 1 to $1.5 \mathrm{~km} \mathrm{~h}^{-1}$ (Kühlmann \& Karst 1967). 


\section{Distribution of sandeel fishing}

The Dogger Bank sandeel fishery is shown to be tightly linked with sandeel life history. It is highly localised within the North Sea and within the Dogger Bank region, tied to the localised abundance of sandeels at shallower sandbanks or ridges. Furthermore, sandeel fishing is highly seasonal (April-June) and concentrated during daylight hours, precisely timed when sandeels are feeding pelagically in schools (Anonymous 1994, Hawkins et al. 1998). Sandeels appear to be relatively free from fishing pressure at night while in the seabed. In fact, frequency distributions of vessel speed confirm that fishers optimally use darkness for long-distance steams. The abrupt start and end of the Dogger Bank sandeel fishing season is not only linked to sandeel seasonality, but also to North Sea-wide distributional shifts of the fishery itself. From Norwegian waters in the first quarter of the year, the sandeelers tend to first arrive at the Dogger Bank by mid-April, and by early summer they tend to move to banks off northeast England and, historically, off Scotland (Hawkins et al. 1998).

Interestingly, the distribution of sandeel fishing effort only matched sandeel numbers at a moderately coarse spatial scale. At the within-grid finer scale effort distribution did not correlate with day sandeel distributions, despite trawling typically occurring during daylight, nor did it correlate with sandeel distribution at night. We recognise that our acoustics provide 'snap-shots' of sandeel abundance at the time of surveys and may not necessarily be good indicators over the time span of a fishing season, even though we did examine fishing effort over weekly to monthly time windows. Nevertheless, fine-scale effort distribution was clearly matched with topographical features, with fishers closely following the shallower ridges and edges of sandbanks. Good sandeel catches may generally be obtained here (Mackinson \& van der Kooij 2006) although not necessarily at a fine spatial scale, as indicated by the fairly poor correlations mentioned above. Indeed, choices of fishing location frequently incorporate knowledge on catch rates from previous years or weeks (cf. Christensen \& Raakjær 2006, E. D. Bell pers. obs.). Hence, it appears that fishers have insufficient knowledge of where the highest concentrations of sandeel schools are found at the time of fishing, perhaps partly due to the high mobility of sandeels during their diurnal migrations. Issues about maneuverability of sandeelers, typically large fishing vessels applying very large trawls, and local obstructions at the seafloor that could potentially damage the light and fine mesh used, may also hinder the fishers' ability to fine-tune effort to local-scale sandeel distributions.

\section{Natural predation during day and night}

Sandeels on the Dogger Bank were preyed upon by no less than 10 fish species, and the stomachs of 9 of these frequently contained sandeels. Per capita sandeel consumption averaged 0.95 in Grid 1 and 0.21 in Grid 2, and this only represents sandeels eaten during the past day or so, the time window over which stomach contents are usually representative, and includes any predator stomachs found empty (Pinnegar et al. 2006). Sandeel predation was tightly linked to sandeel abundance: not only were far more sandeels consumed by predatory fish in the 'high sandeel' Grid 1 than in Grid 2, but also during the 'high sandeel years' 2005 and especially 2006 when compared to the 'low sandeel year' 2004. Nine of the 10 sandeel predator species are of commercial significance to human consumption fisheries. These observations support the consensus that sandeels are an important food species in the North Sea and underline the need to consider sandeel fishery in an ecosystem context (cf. Camphuysen 2005).

Three species dominated all sandeel predation 'events', well over $80 \%$ of which were by whiting, lesser weever and grey gurnard. Of these, only whiting has high commercial significance (although a small market exists for grey gurnard). Indeed, whiting predation on sandeels was previously estimated to be the strongest single feeding interaction amongst North Sea fish populations (Temming et al. 2004). Our study suggests that lesser weever is of comparable importance to whiting as a sandeel predator, at least locally on the Dogger Bank. By comparison, only a small fraction of sandeels was consumed by the species of highest commercial importance, i.e. plaice, haddock, mackerel and cod. However, several of these are currently at historically low stock levels in the North Sea (mackerel, ICES 2006; cod, plaice, ICES 2007) and their historical sandeel predation has undoubtedly been appreciably higher, especially considering the high per capita sandeel consumption and percentage of sandeel in the diet of cod and mackerel observed in our study. Hence, the current predation situation may not be representative of a more pristine state of the Dogger Bank.

Although sandeels are thought to be particularly vulnerable to piscine predation at dusk or dawn when approaching or leaving the seabed (Hobson 1986), our results suggest significant predation during both day and night, with whiting being the predominant predator by day and lesser weever by night (and no clear evidence of such timing for grey gurnard). Daytime predation by whiting is in line with mobile visual hunting tactics as reported previously by Pedersen (2000). Conversely, off the Scottish coast, whiting preyed on sandeels more at night than during the day (Temming \& Mergardt 2002, Temming et al. 2004). Our results 
agree with Temming et al. (2004) in that, within study grids, whiting showed an 'aggregative response' to sandeels (predators aggregating where prey are abundant). The significant positive relationships of whiting abundances and their total and per capita sandeel consumption with daytime sandeel distributions imply that whiting responded to local concentrations of sandeel distributions, which would support reasonably tight predator-prey interactions. Nevertheless, generally higher abundances of whiting in the sandeel-poor Grid 2 (and much lower occurrence of sandeels in their diet here) imply that whiting can also thrive on other prey. As generalist predators, whiting apparently consume sandeels in high quantities and aggregate with them in regions where these are abundant, but can switch to other prey where this is not the case (Pinnegar et al. 2006).

Of all predators, lesser weever appeared to be most tightly linked to sandeels. Lesser weever are bottomdwelling fish that lie buried in sandy seabeds and become active at night (Lewis 1980). They likely target sandeels during twilight when these break loose from the schools to enter the sediment, or when they leave it at dawn (Hobson 1986). Although the close matches between lesser weever and night sandeel abundances are highly suggestive of an aggregative response, we cannot fully exclude the possibility that they simply exhibit similar habitat preferences. Both species require clean medium-grain sands at fairly shallow depths as burying substrate (Lewis 1980, Holland et al. 2005).

Grey gurnard, which preyed fairly extensively on sandeels, did not show predation patterns clearly matching within-grid day or night sandeel distributions. As bottom-dwellers with tactile pectoral fin rays for probing the seafloor, they may well target sandeels on the seabed at night or at dawn or dusk, although they have also been observed to occasionally feed pelagically (Daan et al. 1990). The importance of sandeels in grey gurnard diet was confirmed by significantly higher total sandeel consumption, per capita sandeel consumption, and percentage sandeel in their diet in the 'high' compared to the 'low' sandeel grid. Haddock were found to feed only occasionally on sandeels, in contrast to case studies off Scotland where they did so extensively (cf. Greenstreet et al. 1998, Temming et al. 2004). Notice, however, that many alternative (often invertebrate) prey types were available to this omnivorous species at our Dogger Bank study sites (Pinnegar et al. 2006). Overall, this implies a situation where predators can switch between different prey types in response to local prey availability, suggestive of an ecosystem with many relatively weak (and some strong) links (Link 2002), but where such 'highenergy' prey sources as sandeels (Pedersen \& Hislop 2001), if locally available, are preferred and responded to, demonstrated here by the strong aggregative responses by the dominant predators whiting and lesser weever.

\section{Competing sandeel fishery and natural predators?}

To what extent does large-scale, localised depletion of sandeels on the Dogger Bank deprive natural predators of food? The present study underlines the very localised distributions of sandeels both during the day and at night, and the very aggregated nature of this species may make it more vulnerable to depletion if the fishery can locate these 'patches' (Pitcher 1995). Sandeel fishing effort is shown to be tightly matched with the distribution of sandeels; notably, almost all effort occurred in the 'high sandeel' area of the North West Riff. Even though this 'match' was imperfect at the finest spatial scale examined, the implication is that almost all sandeel fishing is likely to occur within confined, optimal sandeel habitats and during a crucial seasonal time window with realistic potential for localised depletions. At the same time, predatory fish species showed moderate to strong predator-prey relationships with sandeels. Tightness of these links was especially indicated by the significant 'aggregative response' (cf. Temming et al. 2004) of the 2 dominant predators whiting and lesser weever. High occurrence of sandeels in the diets of 7 other predator species, and more extensive sandeel consumption when and where sandeels were more abundant, further underlined the ecological importance of sandeels.

To some extent, the predatory fishes did show fairly generalist diets and were apparently able to switch between prey types depending on local prey availability. Hence, the Dogger Bank predatory fishes might not be as crucially dependent on sandeels as many seabird colonies off Scotland and the Shetlands appear to be (Frederiksen et al. 2004, Poloczanska et al. 2004). Seabirds may depend particularly on sandeels due to high energy requirements, the constraint of only being able to forage close to the surface, and a low ability to switch prey. During the short breeding season, sandeels of a particular size and quality are required to feed growing chicks, in contrast to most predatory fish where reproductive output is more related to feeding and body fat deposition throughout the year. Nevertheless, despite prey switching behaviour, sandeels might well be the preferred prey for many piscine predators, given their high energy content (Pedersen \& Hislop 2001). Indeed, we observed sandeels of all size classes in predator stomachs, from larval to fully grown (length range 0.5 to $19 \mathrm{~cm}$; G. H. Engelhard unpubl. data). This included sizes targeted by the sandeel fishery (>6 cm; Hawkins et al. 1998). A lack of sandeels 
resulting from industrial fishing may well 'force' predatory fish species important to human consumption fisheries to target suboptimal prey with a lower calorific value (cf. Link \& Garrison 2002), leading to reduced growth and condition. Indeed, our preliminary analyses indicate that low sandeel abundances are associated with poorer body condition in several predatory fish species (Engelhard et al. 2007), and reduced condition is likely to impair reproduction and survival chances.

In conclusion, sandeel fishing effort on the Dogger Bank is concentrated when and where sandeels are most available and where, in turn, they are locally preyed upon by at least 10 predatory fish species, including 8 commercially important 'human consumption' species. Therefore, concerns that industrial sandeel fishery may indirectly impact predatory fishes by depriving them of a high-quality prey species might have some basis.

Acknowledgements. This study was funded by the UK Department for the Environment, Food and Rural Affairs (Defra) contract MF0323 (Multispecies Fisheries Management: A comprehensive impact assessment of the sandeel fishery along the English east coast) with additional funding to G.H.E. from Defra contract MA010 (Fisheries supporting studies). We are grateful to the crews of RVs 'Corystes' and 'Cefas Endeavour', and we acknowledge the dedication of all scientists participating in surveys. R. Stafford, S. Jennings, D. Maxwell, A. South and 4 anonymous referees provided valuable discussions and suggestions.

\section{LITERATURE CITED}

Anonymous (1994) Study of the Danish fish meal and fish oil industry. COWIconsult, Lyngby

Anonymous (2003) Industrial boats killing cod feed. UK Fishing News, 27 June 2003

Camphuysen CJ (ed) (2005) Understanding marine foodwebs: an ecosystem approach to sustainable sandeel fisheries in the North Sea. IMPRESS Final Report, Royal Netherlands Institute for Sea Research, Texel

Christensen AS, Raakjær J (2006) Fishermen's tactical and strategic decisions: a case study of Danish demersal fisheries. Fish Res 81:258-267

Daan N, Bromley PJ, Hislop JR, Nielsen NA (1990) Ecology of North Sea fish. Neth J Sea Res 26:343-386

Engelhard GH, Blanchard JL, Righton DA, Mackinson S, Pinnegar JK, Bell ED, van der Kooij J (2007) Industrial fishing, sandeels, and predatory fish condition. ICES CM 2007/ O:39

Forsythe WC, Rykiel EJ Jr, Stahl RS, Wu H, Schoolfield RM (1995) A model comparison for daylength as a function of latitude and day of year. Ecol Model 80:87-95

Frederiksen M, Wanless S, Harris MP, Rothery P, Wilson LJ (2004) The role of industrial fisheries and oceanographic change in the decline of North Sea black-legged kittiwakes. J Appl Ecol 41:1129-1139

Frederiksen M, Wright PJ, Heubeck M, Harris MP, Mavor RA, Wanless S (2005) Regional patterns of kittiwake Rissa tridactyla breeding success are related to variability in sandeel recruitment. Mar Ecol Prog Ser 300:201-211

Freeman S, Mackinson S, Flatt R (2004) Diel patterns in the habitat utilisation of sandeels revealed using integrated acoustic surveys. J Exp Mar Biol Ecol 305:141-154

Greenstreet SPR, McMillan JA, Armstrong E (1998) Seasonal variation in the importance of pelagic fish in the diet of piscivorous fish in the Moray Firth, NE Scotland: a response to variation in prey abundance? ICES J Mar Sci 55:121-133

Hawkins T, Christie J, Coull K (1998) The industrial fishery for sandeels. Atlantic Salmon Trust, Moulin, Pitlochry

> Hobson ES (1973) Diel feeding migrations in tropical reef fishes. Helgol Wiss Meeresunters 24:361-370

> Hobson ES (1986) Predation on the Pacific sand lance, Ammodytes hexapterus (Pisces: Ammodytidae), during the transition between day and night in southeastern Alaska. Copeia 1986:223-226

> Holland GJ, Greenstreet SPR, Gibb IM, Fraser HM, Robertson MR (2005) Identifying sandeel Ammodytes marinus sediment habitat preferences in the marine environment. Mar Ecol Prog Ser 303:269-282

ICES (International Council for the Exploration of the Sea) (2006) Report of the working group on the assessment of mackerel, horse mackerel, sardine and anchovy (WGMHSA), 6-15 September 2005, Vigo, Spain. ICES CM 2006/ACFM:08

ICES (International Council for the Exploration of the Sea) (2007) Report of the ICES advisory committee on fishery management, advisory committee on the marine environment and advisory committee on ecosystems, 2007. ICES Advice, Book 6. ICES, Copenhagen

Jarre A, Palomares ML, Soriano ML, Sambilay VC, Pauly D (1991) Some new analytical and comparative tools for estimating the food consumption of fish. ICES Mar Sci Symp 193:178-184

> Jennings S, Alvsvåg J, Cotter AJR, Ehrich S and others (1999) Fishing effects in northeast Atlantic shelf seas: patterns in fishing effort, diversity and community structure. III. International trawling effort in the North Sea: an analysis of spatial and temporal trends. Fish Res 40:125-134

Kühlmann DHH, Karst H (1967) Freiwasserbeobachtungen zum Verhalten von Tobias-fischschwärmen (Ammodytidae) in der westlichen Ostsee. Z Tierpsychol 24:282-297

Lewis DB (1980) Studies of the biology of the lesser weever fish, Trachinus vipera Cuvier II. Distribution. J Fish Biol 17:127-133

Link JS (2002) Does food web theory work for marine ecosystems? Mar Ecol Prog Ser 230:1-9

Link JS, Garrison LP (2002) Trophic ecology of Atlantic cod Gadus morhua on the northeast US continental shelf. Mar Ecol Prog Ser 227:109-123

Macer CT (1966) Sand eels (Ammodytidae) in the south-western North Sea; their biology and fishery. Fish Invest II 24:1-55

> Mackinson S, van der Kooij J (2006) Perceptions of fish distribution, abundance and behaviour: observations revealed by alternative survey strategies made by scientific and fishing vessels. Fish Res 81:306-315

Mackinson S, Sumaila UR, Pitcher TJ (1997) Bioeconomics and catchability: fish and fishers behaviour during stock collapse. Fish Res 31:11-17

> Mackinson S, Turner K, Righton D, Metcalfe JD (2005) Using acoustics to investigate changes in efficiency of a sandeel dredge. Fish Res 71:357-363

MacLennan DN, Simmonds EJ (1992) Fisheries acoustics. Chapman \& Hall, London

Pedersen J (2000) Food consumption and daily feeding 
periodicity: comparison between pelagic and demersal whiting in the North Sea. J Fish Biol 57:402-416

Pedersen J, Hislop JRG (2001) Seasonal variations in the energy density of fishes in the North Sea. J Fish Biol 59:380-389

Pinnegar JK, van der Kooij J, Engelhard GH, Blanchard JL, Warr KJ, Righton D (2006) Small-scale variability in fish diet and whether or not this reflects local patterns of prey availability. ICES CM 2006/F:06

Pitcher TJ (1995) The impact of pelagic fish behaviour on fisheries. Sci Mar 59:295-306

Poloczanska ES, Cook RM, Ruxton GD, Wright PJ (2004) Fishing vs. natural recruitment variation in sandeels as a cause of seabird breeding failure at Shetland: a modelling approach. ICES J Mar Sci 61:788-797

Reay PJ (1970) Synopsis of biological data on North Atlantic sand eels of the genus Ammodytes (A. tobianus, $A$. dubius, A. americanus and A. marinus). FAO Fisheries Synopsis No. 82. FAO, Rome

Rice J (1995) Food web theory, marine food webs, and what climate change may do to northern marine fish popula-

Editorial responsibility: Matthias Seaman,

Oldendorf/Luhe, Germany tions. In: Beamish JR (ed) Climate change and northern fish populations. Can Spec Publ Fish Aquat Sci 121, National Research Council of Canada, Ottawa, p 561-568

Temming A, Mergardt N (2002) Estimating the mean time between meals in the field from stomach content data and gastric evacuation functions of whiting (Merlangius merlangus L.) feeding on sandeel (Ammodytes marinus Raitt). ICES J Mar Sci 59:782-793

Temming A, Götz S, Mergardt N, Ehrich S (2004) Predation of whiting and haddock on sandeel: aggregative response, competition and diel periodicity. J Fish Biol 64:1351-1372

van der Kooij J, Scott BE, Mackinson S (2008) The effects of environmental factors on daytime sandeel distribution and abundance on the Dogger Bank. J Sea Res (in press)

Winslade P (1974) Behavioural studies on the lesser sandeel Ammodytes marinus (Raitt). I. The effect of food availability on activity and the role of olfaction in food detection. J Fish Biol 6:565-576

Wright PJ, Jensen H, Tuck I (2000) The influence of sediment type on the distribution of the lesser sandeel, Ammodytes marinus. J Sea Res 44:243-256

Submitted: September 13, 2007; Accepted: May 16, 2008

Proofs received from author(s): September 19, 2008 